Hobbs, R.W., Huber, B.T., Bogus, K.A., and the Expedition 369 Scientists Proceedings of the International Ocean Discovery Program Volume 369 publications.iodp.org

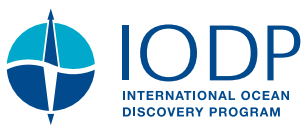

https://doi.org/10.14379/iodp.proc.369.201.2020

Check for updates

\section{Data report: isotopic records for carbonate and organic fractions from IODP Expedition 369, Hole U1515A ${ }^{1}$}

Tracy M. Quan, ${ }^{2}$ Tao Wu, ${ }^{2}$ and the Expedition 369 Scientists $^{3}$

Keywords: International Ocean Discovery Program, IODP, JOIDES Resolution, Expedition 369, Australia Cretaceous Climate and Tectonics, Site U1515, stable carbon isotopes, carbonate, organic carbon, oxygen isotopes, Mentelle Basin
Contents

$\begin{array}{ll}\mathbf{1} & \text { Abstract } \\ \mathbf{1} & \text { Introduction } \\ \mathbf{2} & \text { Methods and materials } \\ \mathbf{2} & \text { Results } \\ \mathbf{3} & \text { Acknowledgments } \\ \mathbf{3} & \text { References }\end{array}$

1 Abstract

2 Methods and materials

3 Acknowledgment

\begin{abstract}
Isotopic measurements of organic carbon $\left(\delta^{13} \mathrm{C}_{\text {org }}\right)$, carbonate carbon $\left(\delta^{13} \mathrm{C}_{\text {carb }}\right)$, and oxygen $\left(\delta^{18} \mathrm{O}_{\text {carb }}\right)$ were made at low stratigraphic resolution on samples from International Ocean Discovery Program (IODP) Expedition 369, Hole U1515A (southeast Indian Ocean). The $\delta^{13} \mathrm{C}_{\text {org }}$ values ranged from $-30.2 \%$ to $-21.0 \%$, with an average of $-24 \%$ o $\pm 2 \%$, whereas $\delta^{13} \mathrm{C}_{\text {carb }}$ values ranged from $0.5 \%$ o to $1.4 \%$ with an average of $1.1 \%$ $\pm 0.3 \%$. Carbonate $\delta^{18} \mathrm{O}_{\text {carb }}$ values averaged $1.1 \%$ o $\pm 0.8 \%$ and ranged from $-0.3 \%$ o to $2.4 \%$. Initial plans were to use the $\delta^{13} \mathrm{C}_{\text {carb }}$ and $\delta^{13} \mathrm{C}_{\text {org }}$ profiles to identify changes in the carbon cycle at the site and to compare local patterns to global records; however, poor core recovery and lack of solid age control limited the number of suitable samples and precluded meaningful interpretation of stratigraphic patterns.
\end{abstract}

\section{Introduction}

One of the main goals of Expedition 369 was to obtain sediment records from the Naturaliste Plateau and Mentelle Basin off southwestern Australia to investigate climate and tectonic changes that occurred in the region during the Cretaceous and Paleogene periods. Located in the eastern Mentelle Basin, Site U1515 was cored to provide a regional record of the timing of tectonic rifting prior to the separation of greater India and Antarctica and to compare eastern Mentelle Basin depocenters to those in the west (Site U1513), as shown in Figure F1 (see the Site U1515 chapter [Huber et al., 2019]). Site U1515 was the shallowest drilled during the expedition.

Only one hole was cored at Site U1515 (512.98 m core depth below seafloor, Method A [CSF-A]). Recovery was low (18.1\%), partic-
Figure F1. Map of the Mentelle Basin showing the location of Site U1515 (red triangle, red text) on the northeastern margin. Other Expedition 369 sites are also shown, particularly Site U1513 (black circle, bold text) on the western side of the basin. Figure modified from Huber et al. (2019).

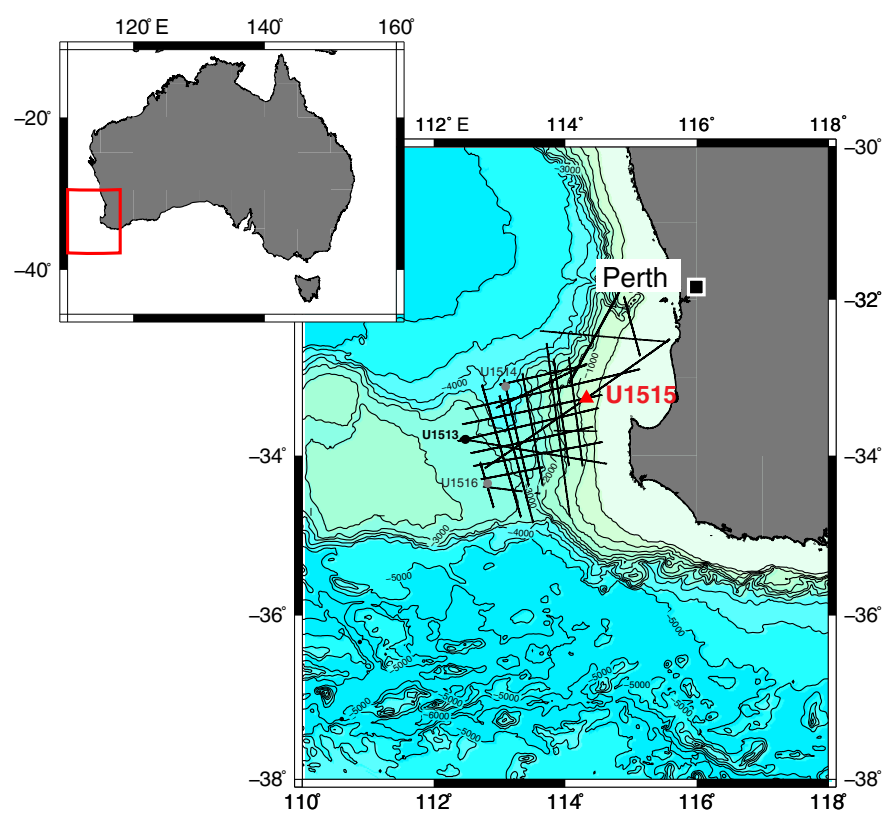

ularly in the middle portions of the hole ( 137-267 m CSF-A), and the absence of calcareous microfossils below Core 369-U1515A20R (190.7 m CSF-A) made age assignments difficult (see the Site

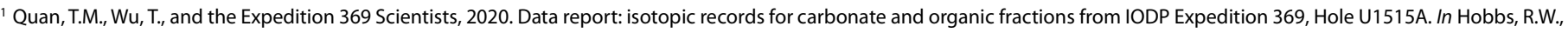
Huber, B.T., Bogus, K.A., and the Expedition 369 Scientists, Australia Cretaceous Climate and Tectonics. Proceedings of the International Ocean Discovery Program, 369: College Station, TX (International Ocean Discovery Program). https://doi.org/10.14379/iodp.proc.369.201.2020

2 Boone Pickens School of Geology, Oklahoma State University, Stillwater OK 74078, USA. Correspondence author: tracy.quan@okstate.edu

${ }^{3}$ Expedition 369 Scientists' addresses.

MS 369-201: Received 15 July 2019 . Accepted 30 October 2019 . Published 17 January 2020

This work is distributed under the Creative Commons Attribution 4.0 International (CC BY 4.0) license. (c))BY 
U1515 chapter [Huber et al., 2019]). Hole U1515A is divided into two lithostratigraphic units (see the Site U1515 chapter [Huber et al., 2019]). Unit I is calcareous ooze to chalk of Pleistocene to late Campanian age. Unit II is composed of interbedded black sandstone, claystone, and siltstone; because of poor recovery, the age of Unit II could not be conclusively established but may extend into the Middle Jurassic (Wainman et al., 2019). The depositional environment for Unit II is thought to be fluvial-lacustrine in nature.

For Hole U1515A, low-resolution measurements for both organic $\left(\delta^{13} \mathrm{C}_{\text {org }}\right)$ and carbonate $\left(\delta^{13} \mathrm{C}_{\text {carb }}\right)$ carbon isotopes and carbonate oxygen isotopes $\left(\delta^{18} \mathrm{O}_{\text {carb }}\right)$ were determined. Carbon isotope profiles can be used to characterize several aspects of carbon sources and cycling (e.g., Broecker and Peng, 1982; Meyers, 1994, 1997; Galimov, 2006, and references within). Carbon isotope profiles can also be used to correlate sedimentary sequences and identify geologic events between different locations, including oceanic anoxic events and mass extinctions, by comparing these profiles with known perturbations in the global carbon cycle (e.g., Corfield, 1994; Tsikos et al., 2004; D’Hondt, 2005; Erbacher et al., 2005; Jenkyns, 2010, and references within; Hasegawa et al., 2013). Oxygen isotope profiles of carbonates serve as proxies for paleotemperature and salinity and have been used to identify changes in circulation patterns and climate trends (e.g., Urey, 1947; Emiliani, 1954; Shackleton, 1967; Rostek et al., 1993; Zachos et al., 2001).

\section{Methods and materials}

A total of 34 samples were analyzed for $\delta^{13} C_{\text {org }}, \delta^{13} C_{\text {carb }}$, and $\delta^{18} \mathrm{O}_{\text {carb }}$. The samples were previously used for the shipboard moisture and density analyses and were roughly $10 \mathrm{~cm}^{3}$ in size.

All analyses were performed in the geochemistry laboratories at the Boone Pickens School of Geology, Oklahoma State University (USA). Samples were oven-dried at $60^{\circ} \mathrm{C}$ overnight, powdered using an agate mortar and pestle, and then dried again at $60^{\circ} \mathrm{C}$ overnight.

For $\delta^{13} \mathrm{C}_{\text {org }}, 20-50 \mathrm{mg}$ of sample was weighed into silver capsules, and then hydrochloric acid was added until all carbonate was dissolved. Samples were again dried in a $60^{\circ} \mathrm{C}$ oven. Then a small amount of vanadium pentoxide was added to enhance combustion. The silver capsule was folded and wrapped in a tin capsule. Samples were measured using a using a Costech elemental analyzer coupled to a Thermo Finnigan Delta Plus isotope ratio mass spectrometer (IRMS). The $\delta^{13} C_{\text {org }}$ isotopic compositions are reported relative to Vienna Peedee belemnite (VPDB); Urea \#1 (Indiana University) and USGS40 standards were used for two-point carbon isotope calibrations (Coplen et al., 2006). Replicates of $\delta^{13} \mathrm{C}_{\text {org }}$ standards had a standard deviation $(1 \sigma)$ of $0.1 \%$; replicates for Site U1515 samples had a standard deviation of less than $0.2 \%$.

For $\delta^{13} \mathrm{C}_{\text {carb }}$ and $\delta^{18} \mathrm{O}_{\text {carb }}, 200-400 \mu \mathrm{g}$ of sample was measured into $12 \mathrm{~mL}$ glass vials (Labco Exetainer) and sealed with butyl rubber septa. The headspace was flushed for $800 \mathrm{~s}$ with helium to re- move air. A $0.5 \mathrm{~mL}$ aliquot of $100 \%$ orthophosphoric acid (density $=$ $1.92 \mathrm{~g} / \mathrm{cm}^{3}$ ) was injected to release $\mathrm{CO}_{2}$ from carbonate, and the sample was allowed to react for $2 \mathrm{~h}$ at room temperature. The $\mathrm{CO}_{2}$ was measured using a Thermo Finnigan Delta Plus IRMS with a GasBench II interface and PAL autosampler. A total of 15 subsamples from the headspace were measured per sample, and the $\delta^{13} C_{\text {carb }}$ and $\delta^{18} \mathrm{O}_{\text {carb }}$ values were calculated by averaging the last 10 subsamples. Carbonate isotopic values are reported relative to VPDB, and NBS19 and an in-house carbonate mixture were used as standards. Standard deviation from the average for standards and samples was less than $0.2 \%$ for $\delta^{13} \mathrm{C}_{\text {carb }}$ and less than $0.6 \%$ for $\delta^{18} \mathrm{O}_{\text {carb }}$. The high standard deviation for some of the $\delta^{18} \mathrm{O}_{\text {carb }}$ measurements was likely the result of a small amount of residual air in the phosphoric acid.

\section{Results}

Values for $\delta^{13} \mathrm{C}_{\text {org }}, \delta^{13} \mathrm{C}_{\text {carb }}$, and $\delta^{18} \mathrm{O}_{\text {carb }}$ from Hole U1515A are given in Table T1 and shown in Figure F2. Shipboard evaluations of total organic carbon (TOC) and carbonate concentrations, natural gamma radiation (NGR), basic lithology, magnetostratigraphy, and estimated ages are also shown in Figure F2.

\section{Organic carbon isotopic data}

For $\delta^{13} \mathrm{C}_{\text {org }}$, values ranged from $-30.2 \%$ o to $-21.0 \%$. Two samples did not contain sufficient organic carbon to yield reliable measurements. The profile with depth shows a slight decrease through Unit II from approximately $-24 \%$ at the bottom of the hole to a minimum of $-30.2 \%$ at $127.94 \mathrm{~m}$ CSF-A (369-U1515A-15R-1, 14-16 $\mathrm{cm}$ ) and then a steady increase to the top of the hole. This pattern could reflect changes in the relative amount of terrestrial organic matter input over time, but the large gaps in the cored material and the low-resolution sampling make it difficult to interpret the record as a whole. Lack of solid age control also makes it difficult to compare the Hole U1515A profile with other $\delta^{13} C_{\text {org }}$ records.

\section{Carbonate isotopic data}

The $\delta^{13} \mathrm{C}_{\text {carb }}$ and $\delta^{18} \mathrm{O}_{\text {carb }}$ records extend only from the top of Hole U1515A to $127.94 \mathrm{~m}$ CSF-A. Samples from below $127.94 \mathrm{~m}$ CSF-A did not contain sufficient carbonate to produce reliable measurements. This claim is consistent with shipboard measurements of carbonate concentrations and lack of calcareous microfossils at depth (see the Site U1515 chapter [Huber et al., 2019]). Carbon isotope values ranged from $0.5 \%$ to $1.4 \%$, and $\delta^{18} \mathrm{O}_{\text {carb }}$ values ranged from $-0.3 \%$ to $2.4 \%$. Unlike the organic carbon measurements, neither the $\delta^{13} \mathrm{C}_{\text {carb }}$ nor $\delta^{18} \mathrm{O}_{\text {carb }}$ values show an obvious trend with depth, but the short interval, low resolution, and lack of solid age control for this profile make it difficult to interpret or compare with global records.

Table T1. Carbon data, Hole U1515A. This table is available in CSV format. 
Figure F2. Isotopic values and shipboard data, Hole U1515A. cps = counts per second. Figure modified from Huber et al. (2019).

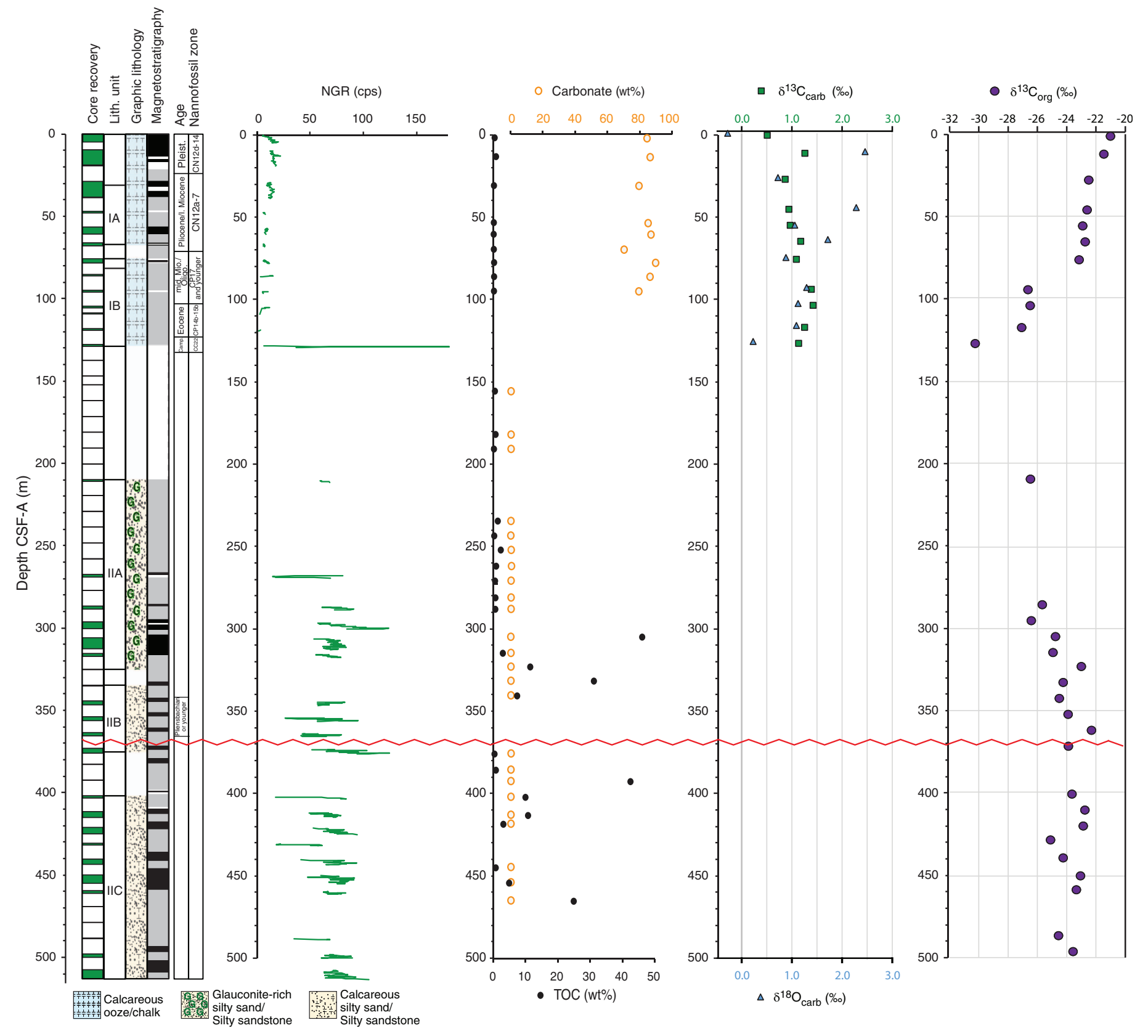

\section{Acknowledgments}

The authors would like to thank IODP for making the samples available and for access to the shipboard measurements. We would also like to thank Dr. Colin Macpherson for his thoughtful review. T.M. Quan would like to thank the US Science Support Office (USSSP) for salary support during the cruise.

\section{References}

Broecker, W.S., and Peng, T.-H., 1982. Tracers in the Sea: Palisades, NY (Eldigio Press).

Coplen, T.B., Brand, W.A., Gehre, M., Gröning, M., Meijer, H.A.J., Toman, B., and Verkouteren, R.M., 2006. New guidelines for $\delta^{13} C$ measurements.
Analytical Chemistry, 78(7):2439-2441. https://doi.org/10.1021/ac052027c

Corfield, R.M., 1994. Palaeocene oceans and climate: an isotopic perspective. Earth-Science Reviews, 37(3-4):225-252. https://doi.org/10.1016/0012-8252(94)90030-2

D'Hondt, S., 2005. Consequences of the Cretaceous/Paleogene mass extinction for marine ecosystems. Annual Review of Ecology, Evolution, and Systematics, 36:295-317.

https://doi.org/10.1146/annurev.ecolsys.35.021103.105715

Emiliani, C., 1954. Temperature of Pacific bottom waters and polar superficial waters during the Tertiary. Science, 119(3103):853-855. https://doi.org/10.1126/science.119.3103.853

Erbacher, J., Friedrich, O., Wilson, P. A., Birch, H., and Mutterlose, J., 2005. Stable organic carbon isotope stratigraphy across Oceanic Anoxic Event 2 
of Demerara Rise, western tropical Atlantic. Geochemistry, Geophysics, Geosystems, 6(6):Q06010. https://doi.org/10.1029/2004GC000850

Galimov, E.M., 2006. Isotope organic geochemistry. Organic Geochemistry, 37(10):1200-1262. https://doi.org/10.1016/j.orggeochem.2006.04.009

Hasegawa, T., Crampton, J.S., Schiøler, P., Field, B., Fukushi, K., and Kakizaki, Y., 2013. Carbon isotope stratigraphy and depositional oxia through Cenomanian/Turonian boundary sequences (Upper Cretaceous) in New Zealand. Cretaceous Research, 40:61-80. https://doi.org/10.1016/j.cretres.2012.05.008

Huber, B.T., Hobbs, R.W., Bogus, K.A., Batenburg, S.J., Brumsack, H.-J., do Monte Guerra, R., Edgar, K.M., Edvardsen, T., Garcia Tejada, M.L., Harry, D.L., Hasegawa, T., Haynes, S.J., Jiang, T., Jones, M.M., Kuroda, J., Lee, E.Y., Li, Y.-X., MacLeod, K.G., Maritati, A., Martinez, M., O'Connor, L.K., Petrizzo, M.R., Quan, T.M., Richter, C., Riquier, L., Tagliaro, G.T., Wainman, C.C., Watkins, D.K., White, L.T., Wolfgring, E., and Xu, Z., 2019. Site U1515. In Hobbs, R.W., Huber, B.T., Bogus, K.A., and the Expedition 369 Scientists, Australia Cretaceous Climate and Tectonics. Proceedings of the International Ocean Discovery Program, 369: College Station, TX (International Ocean Discovery Program). https://doi.org/10.14379/iodp.proc.369.106.2019

Jenkyns, H.C., 2010. Geochemistry of oceanic anoxic events. Geochemistry, Geophysics, Geosystems, 11(3):Q03004. https://doi.org/10.1029/2009GC002788

Meyers, P.A., 1994. Preservation of elemental and isotopic source identification of sedimentary organic matter. Chemical Geology, 114(3-4):289-302. https://doi.org/10.1016/0009-2541(94)90059-0
Meyers, P.A., 1997. Organic geochemical proxies of paleoceanographic, paleolimnologic, and paleoclimatic processes. Organic Geochemistry, 27(5-6):213-250. https://doi.org/10.1016/S0146-6380(97)00049-1

Rostek, F., Runhand, G., Bassinot, F.C., Muller, P.J., Labeyrie, L.D., Lancelot, Y., and Bard, E., 1993. Reconstructing sea surface temperature and salinity using $\delta^{18} \mathrm{O}$ and alkenone records. Nature, 364(6435):319-321. https://doi.org/10.1038/364319a0

Shackleton, N., 1967. Oxygen isotope analyses and Pleistocene temperatures re-assessed. Nature, 215(5096):15-17. https://doi.org/10.1038/215015a0

Tsikos, H., Jenkyns, H.C., Walsworth-Bell, B., Petrizzo, M.R., Forster, A., Kolonic, S., Erba, E., et al., 2004. Carbon-isotope stratigraphy recorded by the Cenomanian-Turonian oceanic anoxic event: correlation and implications based on three key localities. Journal of the Geological Society (London, United Kingdom), 161:711-719. https://doi.org/10.1144/0016-764903-077

Urey, H.C., 1947. The thermodynamic properties of isotopic substances. Journal of the Chemical Society, 0:562-581. https://doi.org/10.1039/JR9470000562

Wainman, C.C., Borissova, I., Harry, D.L., Hobbs, R.W., Mantle, D.J., Maritati, A., Lee, E.Y., and the Expedition 369 Scientists, 2019. Evidence for nonmarine Jurassic to Earliest Cretaceous sediments in the pre-breakup section of the Mentelle Basin, southwestern Australia. Australian Journal of Earth Sciences. https://doi.org/10.1080/08120099.2019.1627581

Zachos, J., Pagani, M., Sloan, L., Thomas, E., and Billups, K., 2001. Trends, rhythms, and aberrations in global climate $65 \mathrm{Ma}$ to present. Science, 292(5517):686-693. https://doi.org/10.1126/science.1059412 